\title{
Weeds on Soybeans Crop After the Application of the Association of the Herbicides Imazapic + Imazapyr on Different Liming Rates in a No-till Cropping System
}

\author{
Lucas Rizzon Ferreira $^{1}$, Taísa Dal Magro ${ }^{1}$, Elaine Damiani Conte ${ }^{1}$, Marco Thúlio Monego ${ }^{1}$ \\ \& Lucas de Ross Marchioretto ${ }^{2}$ \\ ${ }^{1}$ Universidade de Caxias do Sul (UCS), Vacaria, RS, Brazil \\ ${ }^{2}$ Universidade do Estado de Santa Catarina (UDESC), Lages, SC, Brazil \\ Correspondence: Taísa Dal Magro, Universidade de Caxias do Sul (UCS), 95200-000, Av. Frei Cândido Bampi \\ 2800, Vacaria, RS, Brazil. E-mail: tdmagro1@ucs.br
}

\author{
Received: March 7, $2018 \quad$ Accepted: April 8, $2018 \quad$ Online Published: May 15, 2018 \\ doi:10.5539/jas.v10n6p238 URL: https://doi.org/10.5539/jas.v10n6p238
}

\begin{abstract}
The repeated use of the herbicide glyphosate has selected weed resistant species to this molecule. The combination of the tank-mix imazapic + imazapyr (Cultivance ${ }^{\circledR}$ technology) turns out being an alternative on the management of glyphosate resistant weeds. The interaction of these molecules with the soil's chemical properties with the spraying frequency, and the weed diversity are yet unknown. This study evaluated the effects of liming at the weed incidence on the soybeans crop treated with the association of herbicides imazapic + imazapyr in a no-till cropping system. The experiment was installed at the field in a RCBD with four replications. The experiment was conducted in a factorial arrangement $5 \times 2$ with five rates of calcitic limestone $(0,2.5,5$, 12.5 , and $30 \mathrm{ton} / \mathrm{ha}$ ) and two corresponding to the presence or absence of the herbicides imazapic $+\mathrm{imazapyr}$ (rate of $100 \mathrm{~g} / \mathrm{ha}$ of the commercial product Soyvance ${ }^{\circledR}$ ) sprayed in a spray-plant system. After 40 months of surface-liming, the soybean cultivar Lancer ${ }^{\circledR}$ was planted in a no-till field, and it was evaluated: frequency and abundance of weeds, and the chemical soil parameters: $\mathrm{pH}, \mathrm{Ca}, \mathrm{H}+\mathrm{Al}$, and $\mathrm{Mg}$ at the depth of 0-10 $\mathrm{cm}$. The most abundant weeds observed were: Desmodium spp., Schlechtendalia luzulifolia, Digitaria horizontalis, Raphanus sativus and Cyperus spp., with predominance of dicot species. In conclusion, as the surface-liming rate was increased, the greater the frequency of dicot weeds, and the lesser the monocots were found in the area.
\end{abstract}

Keywords: cultivance ${ }^{\circledR}$, Glycine max, imidazolinones

\section{Introduction}

There are multiple factors that interfere on the soybeans cropping yield such as the crop management in terms of fertilization, diseases, pests and weeds. The latter when not properly managed may lead to losses up to $80 \%$ (Pittelkow, Jakelaitis, Conus, Oliveira, Gil, Assis, \& Borchartt, 2009).

The competition between the soybeans crop and the weeds are not only for light and water, but also for nutrients. In contrast to pests or diseases attack, usually occasioned by one or a few species, weed's infestation may come about with various species emerging at different timings, which struggles the control (Volpe, Donadon, \& Verde, 2011).

The most outstanding features that bring the weeds to be tough competitors are: quick germination and initial growth, abundant root system, great capacity to uptake water and nutrients out of the soil, elevated water use efficiency, and great production and dissemination of propagules (Vargas \& Roman, 2006).

At the soybeans crop, there are several weed control options, at the crop's pre or post-emergence. Nevertheless, the registered active ingredients belong to quite a few mechanisms of action, which added up to the great number of herbicide resistant weed species, resulting to limited control options (Heap, 2018). For the weed management at field's burn down, the producers usually use herbicides such as ammonium glufosinate or paraquat aiming a wider weed control spectrum. However, the constant use of such molecules have selected resistant weed species (Heap, 2018). 
A new available technology to the weed control on the soybeans crop, the Cultivance ${ }^{\circledR}$ system, allows for the usage of herbicides of the chemical group of the imidazolinones like imazapyr and imazapic on the weed control, as an alternative to glyphosate (Fraga, Ruchel, Duarte, Vieira, Oliveira, Vargas, \& Agostinetto, 2016). The Cultivance ${ }^{\circledR}$ system hitches on genetically modified soybean cultivars with remarkable yield potential, allowing to use an herbicide of wide control spectrum in the management of troublesome dicot and monocot weeds, making it a new production system. This new system offers to producers an opportunity to rotate GMO technologies, assisting on the management of several weeds, and enhancing the lifespan of such technologies (Embrapa, 2016).

The herbicide part of the Cultivance ${ }^{\circledR}$ system belongs to the chemical group of the imidazolinones and is registered with the commercial available label Soyvance Pre ${ }^{\circledR}$. The application of the herbicide is done on the soil right after the crop's planting until a limit on the soybeans growth stage V1, the so called plant-spray system. The time an herbicide remains active in the soil is essential to the determination of the weed control period, as well as the identification of the potential carryover that remains in the soil and the risks to the succeeding crops (Karam, 2016).

Amongst the soil features, $\mathrm{pH}$ affects the persistence and degradation of several herbicides. Some herbicides are more persistent in conditions of soil $\mathrm{pH}$ above 7.0, i.e. the triazines. However, the sulfonylureas have diminished degradation rate when the soil $\mathrm{pH}$ is above 6.8 (Karam, 2016).

The soils of tropical and subtropical regions are normally acid and contain high levels of exchangeable $\mathrm{Al}$ (Ciotta, Bayer, Ernani, Fontoura, Wobeto, \& Albuquerque, 2004), which constitutes an obstacle for the development and production of the majority of the vegetal species.

In such soils liming is a common and important practice to maximize crop yield due to the products derived from the limestone dissolution that react with the soil colloids, and then enhance $\mathrm{pH}$, the levels of $\mathrm{Ca}, \mathrm{Mg}$ and the bases saturation, besides diminishing exchangeable $\mathrm{Al}$ and $\mathrm{Mn}$ (Soratto \& Crusciol, 2008). In a no-till system the acidity amelioration is done by surface-liming without incorporation (Rodrighero, Barth, \& Caires, 2015).

Weeds are usually more competitive in regards to the crops, at soils with elevated nutrient levels, which may lead on in herbicide dependency to keep weed control acceptable (Di Tomaso, 1995).

Information about the weed response to different soil chemical conditions and the interference of such aspects on the herbicide effects constitute a fundamental component to the success of the weed control strategy. Thus, the objective of this trial was to evaluate the effect of liming on the incidence of weed on soybeans crop with the application of the herbicide association imazapic + imazapyr in a no-till cropping system.

\section{Method}

The experiment was carried out in an experimental field at the University of Caxias do Sul (UCS) at the municipality of Vacaria-RS with geographical coordinates $28^{\circ} 26^{\prime} \mathrm{S}$ and $50^{\circ} 26^{\prime} \mathrm{W}$, and altitude of $971 \mathrm{~m}$, on a brown oxisol (Embrapa, 2013) in a no-till cropping system.

The experimental design was randomized complete blocks with four replications. Each experimental unit had an area of $25 \mathrm{~m}^{2}(5 \times 5 \mathrm{~m})$. On the experimental area, it was applied five rates of calcitic limestone (TRNP 100\%) being: $0,2.5,5,12.5$ and 30 ton/ha (Table 1) applied at soil surface on 2012. The area was left at fallow without the traffic of machinery until the cropping season of 2015/16 where it was planted no-till maize.

The experiment at the cropping season of 2016/17 was conducted in a factorial arrangement $5 \times 2$ with five rates of surface liming $(0,2.5,5,12.5$ and $30 \mathrm{ton} / \mathrm{ha})$ and two corresponding to the presence or absence of the herbicide commercially sold as a co-pack imazapic + imazapyr (rate of $100 \mathrm{~g} / \mathrm{ha}$ of the commercial product Soyvance ${ }^{\circledR}$ ) sprayed in a plant-spray system. After spraying the herbicide, it was planted the soybeans crop of the cultivar Lança ${ }^{\circledR}$ in a plant density of 10.5 plants $/ \mathrm{m}$ conducted in a no-till system.

The burn-down spraying was done with the application of $1.6 \mathrm{Kg} / \mathrm{ha}$ of glyphosate (Roundup $\mathrm{WG}^{\circledR}$ ), and then 2 $\mathrm{L} / \mathrm{ha}$ of paraquat $\left(\mathrm{Gramoxone}^{\circledR}\right)$. Fertilization at planting was $300 \mathrm{~kg} / \mathrm{ha}$ of triple superphosphate and $100 \mathrm{Kg} / \mathrm{ha}$ of potassium chloride.

The phytosanitary treatments performed were: Fox ${ }^{\circledR}$ added on Aureo ${ }^{\circledR}$ at the rates of 400 and $300 \mathrm{ml} / \mathrm{ha}$, respectively, in 11 and 27 of January and 04 of March of 2017. At the application of Jan $27^{\text {th }}$ it was added on Orthene ${ }^{\circledR}$ at the rate of $1 \mathrm{~kg} / \mathrm{ha}$, and in the application of Mar $4^{\text {th }}$ Lorsban $^{\circledR}$ at the rate of $1 \mathrm{~L} / \mathrm{ha}$. In Feb $15^{\text {th }}$ it was applied Folicur $^{\circledR}$, Elatus ${ }^{\circledR}$, Certero $^{\circledR}$, Decis $^{\circledR}$ and Nimbus ${ }^{\circledR}$ at the rates of $600 \mathrm{ml}, 200 \mathrm{~g}, 50 \mathrm{ml}, 300 \mathrm{ml}$ and 300 $\mathrm{ml} / \mathrm{ha}$, respectively. 
The evaluated parameters were: frequency and abundance of weeds and the soil's chemical parameters: $\mathrm{pH}$, $\mathrm{H}+\mathrm{Al}, \mathrm{Ca}$ and $\mathrm{Mg}$ at a depth of $0-10 \mathrm{~cm}$.

The evaluations of the weed population were done in a vegetation classification square of $1 \times 1 \mathrm{~m}$ with a weed cover-abundance scale (Braun-Blanquet, 1979), assessed randomly in the plots, not considering the edges of $1 \mathrm{~m}$ of each plot's extremity at 40 days after the emergence of the soybeans crop. It was evaluated the total number of present weeds, and the number per specie. The weed frequency was evaluated by identifying and counting the number of weed species per plot; the abundance was calculated by the total number of individuals per specie divided by the total of treatments that contained the specie (Adegas, Oliveira, Vieira, Prete, Gazziero, \& Voll, 2010).

The soil sampling for the chemical characterization of the soil layer of $0-10 \mathrm{~cm}$ were done after 40 months after surface-liming. In these samples, it was determined the $\mathrm{pH}$ values and the levels of $\mathrm{H}+\mathrm{Al}, \mathrm{Ca}^{2+} \mathrm{and}^{\mathrm{Mg}}{ }^{2+}$ (Tedesco, Gianello, Bissani, Bohnen, \& Wolkweiss, 1995).

In this trial, it was correlated the soil $\mathrm{pH}, \mathrm{H}+\mathrm{Al}, \mathrm{Ca}$ and $\mathrm{Mg}$ of the treatments with the surface-liming (2.5, 5, 12.5 and $30 \mathrm{ton} / \mathrm{ha}$ ) with the weed incidence in the presence and absence of the spray of the herbicides imazapyr + imazapic.

The results were subjected to analysis of variance $(\mathrm{p} \leq 0.05)$ and complemented with descriptive statistics and analysis of correlation. For evaluating the existing relations between soil chemical characteristics and weed frequency, it was obtained the linear correlations between all analyzed chemical parameters and the weed frequency. The significance of the adjustments of the model to the data was determined through the $\mathrm{F}$ test at $5 \%$ of probability.

\section{Results and Discussion}

On the parameters related to weeds, in function of limestone rates and application of herbicides, there was correlation with the soil's chemical parameters, also exposed with the use of descriptive statistics (Figure 1 and Table 1).

For the weed frequency, there was no effect of the herbicide and its interaction with limestone rate, indicating that liming does not interfere on the control effectiveness of the herbicide association imazapyr + imazapic, and consequently on the weed frequency of dicots and monocots. Thus, the correlation data presented are the mean of the presence and absence of the herbicides (Figure 1).

In general, it can be observed that the dicot class were the ones with the highest frequency, independently of liming rate. In average, the predominance was $73.7 \%$ higher of dicot species in comparison to $26.3 \%$ of monocots (Table 1).

Table 1. Weed frequency (\%) after the application of the association of herbicides imazapyr + imazapic in different rates of surface-liming. Vacaria, RS, 2017

\begin{tabular}{lll}
\hline Rates of limestone (ton/ha) & Monocots & Dicots \\
\hline 0 & 23.9 & 76.1 \\
2.5 & 31.8 & 68.2 \\
5.0 & 30.6 & 69.4 \\
12.5 & 26.0 & 74.0 \\
30.0 & 19.1 & 80.9 \\
\hline
\end{tabular}


A

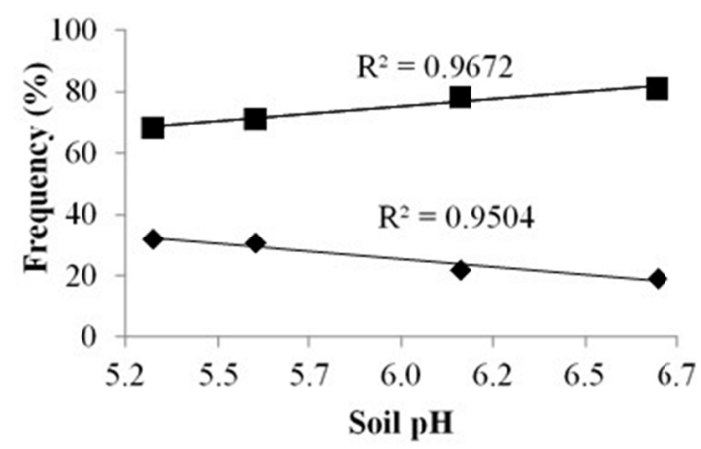

C

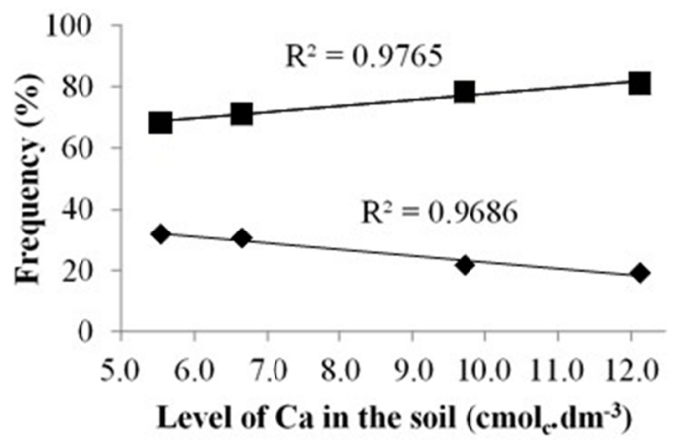

B

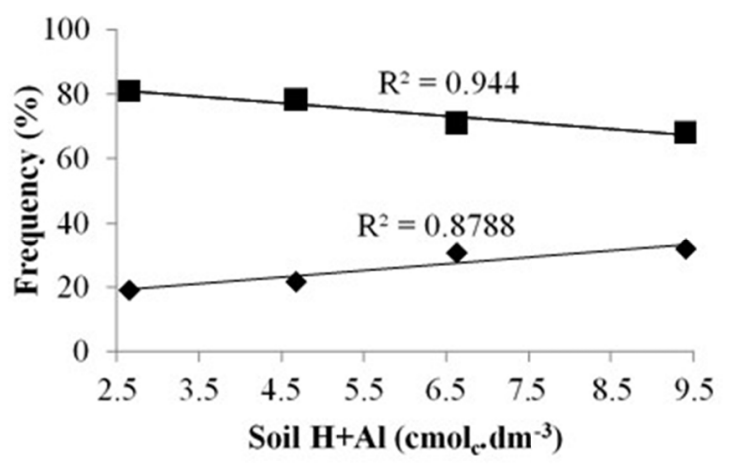

D

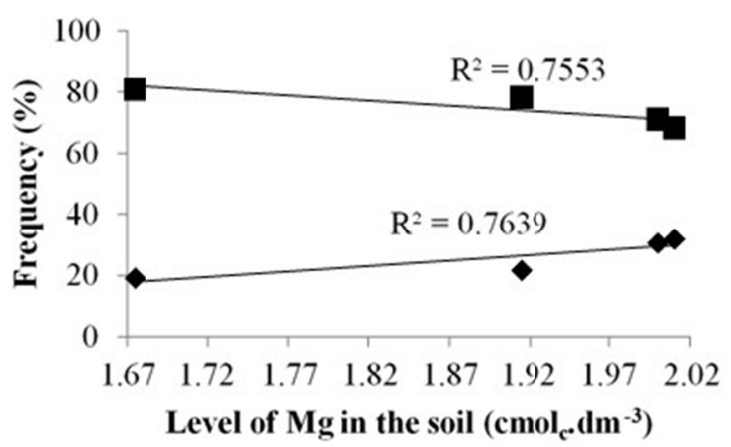

Figure 1. Correlation between frequency of weeds and $\mathrm{pH}(\mathrm{A})$, hydrogen + aluminum $(\mathrm{H}+\mathrm{Al})(\mathrm{B})$, level of calcium $(\mathrm{Ca})(\mathrm{C})$ and level of magnesium $(\mathrm{Mg})(\mathrm{D})$ in the soil, at the depth of $0-10 \mathrm{~cm}$, with and without the application of the herbicide imazapic + imazapyr, with the elevation of liming rate. $\$$ : Monocots; $\mathbf{m}$ : Dicots. Vacaria, RS, 2017

According to the results found by De Sousa et al. (2003), the number of monocot plants were smaller in the treatment with complete fertilization, while the number of dicots were $74 \%$ greater. These data corroborate with the ones observed in this trial, as at a soil ameliorated condition, the weed predominance was made of dicots.

For the $\mathrm{pH}$ soil's chemical property, there was significant correlation with the weed frequency being negative to monocot and positive to dicot species (Figure 1A). The same pattern was observed in regards to potential acidity $(\mathrm{H}+\mathrm{Al})$, but in reverse relation, that is, the measure increases the potential acidity, decreases dicots and increases monocots (Figure 1B). This occurs because the potential acidity represented by $\mathrm{H}+\mathrm{Al}$ decreases with the $\mathrm{pH}$ enhancement. According to Souza et al. (2007), in acid soils the enhancement of the $\mathrm{pH}$ and the consequent decrease in the $\mathrm{Al}$ activity can be considered as adaptation mechanisms of plant species and varieties to the harsh conditions of soil acidity. Therefore, this study suggests that in less acid soils, there is a greater adaptation of dicot weeds.

It was observed that as the Ca levels enhanced, the frequency of dicot weeds was increased, and the frequency of monocots decreased (Figure 1C). According to Pistelli (1985), the interference in the crops is dependent on the infesting vegetal community (specie, density and distribution), and the environment (soil, weather and management), etc.

The levels of $\mathrm{Mg}$ in the soil were also significantly correlated with the weed frequency (Figure 1D). However, in reverse relation to $\mathrm{Ca}$, that is, as the $\mathrm{Mg}$ soil content increased, the frequency of dicots was decreased, and increased the frequency of monocots. According to Anghinoni et al. (1989), the plant's nutrient uptake ability depends on the magnitude and the morphology of the root system, and the efficiency that these nutrients are absorbed by the roots. Chapin (1980) states that some weed species uptake more nutrients per root biomass unit than other crops, attributing this fact to the breeding that the weeds were subjected along the years, fully devoted to the plant's survival in harsh conditions. Some weed species present in soils containing high levels of these 
nutrients become more competitive than the crops due to higher efficiency on nutrient uptake and metabolization (Di Tomaso, 1995).

The results evidence elevated correlations between weeds and the soil's chemical parameters promoted by surface liming. However, as these parameters are altered concomitantly to liming, the influence of weeds could be attributed to only one of these factors in isolated or combined ways with the others.

According to Oliveira and Freitas (2008), during the weed management in a cropping field, the weed phytosociological survey is fundamental, as from the results it is possible to define the management that will take place, the moment, and how it is going to be executed, because the infestation conditions are quite variable and the management possibilities may be diverse.

The most abundant weeds found in the plots were: Desmodium spp. with approximately $80 \%$ of incidence, Schlechtendalia luzulifolia also with approximately $80 \%$, Digitaria horizontalis with $73 \%$, Raphanus sativus with 66\%, and Cyperus spp. with approximately $30 \%$ of incidence (Table 2).

It was identified 14 weed species, being 3 species of monocots Digitaria horizontalis, Cyperus spp., Lolium multiflorum and 11 species of dicots being Desmodium spp., Schlechtendalia luzulifolia, Vicia craca, Conyza bonariensis, Euphorbia heterophylla, Raphanus sativus, Aeschynomene rudis, Nicandra physalodes, Echinodorus grandiflorus, Amaranthus spp., Parthenium hysterophorus L.

Table 2. Abundance of weeds (\%) on the soybeans crop at different limestone rates. Vacaria, RS, 2017

\begin{tabular}{|c|c|c|c|c|c|c|c|c|c|c|c|c|c|c|c|}
\hline Treatment & Herbicide & 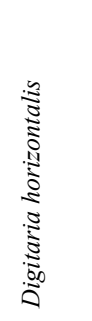 & 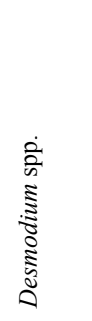 & 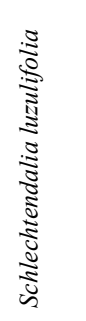 & 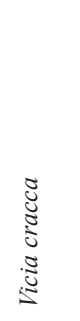 & 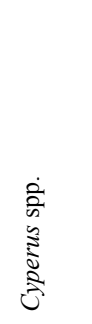 & 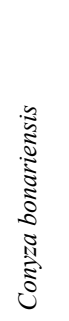 & 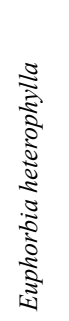 & 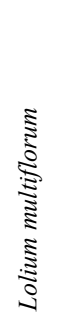 & 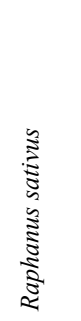 & 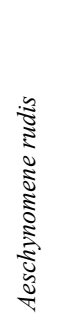 & 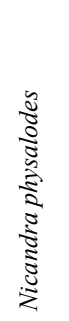 & 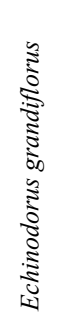 & 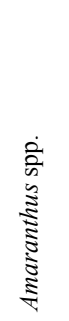 & 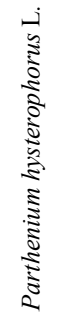 \\
\hline \multirow[t]{2}{*}{ Control } & Absence & 5.25 & 8.75 & 7 & 0.75 & 5.25 & 0.25 & 1 & 0.25 & 5 & 0 & 0 & - & - & - \\
\hline & Presence & 4.5 & 8.25 & 4.5 & 0.25 & 1.5 & 0.75 & 1 & 0 & 2.75 & 0.5 & 1 & - & - & - \\
\hline \multirow[t]{2}{*}{2.5} & Absence & 14.25 & 10.75 & 7.25 & 1.5 & 1.75 & 0.25 & 0.25 & 0.25 & 10.25 & - & - & 2 & - & - \\
\hline & Presence & 12 & 10.75 & 2.75 & 1 & 1.75 & 0 & 0 & 0 & 5.75 & - & - & 0.5 & - & - \\
\hline \multirow[t]{2}{*}{5} & Absence & 7.75 & 15.5 & 13.25 & 1.5 & 4.25 & 0 & - & - & 8 & 0.25 & 0 & 3.25 & 0.25 & - \\
\hline & Presence & 5.5 & 4.5 & 3.5 & 1 & 5.5 & 0.25 & - & - & 8.75 & 0.5 & 0.75 & 0.5 & 0.5 & - \\
\hline \multirow[t]{2}{*}{12.5} & Absence & 8.25 & 2.25 & 9.75 & 1 & 1 & 0.5 & 1 & - & 4 & - & 1 & - & - & 0 \\
\hline & Presence & 4.25 & 4.5 & 11 & 1.75 & 2 & 0 & 0 & - & 11 & - & 0 & - & - & 0.5 \\
\hline \multirow[t]{2}{*}{30} & Absence & 5 & 10.5 & 13.75 & 2 & 4.25 & 1.75 & 1.5 & - & 3.75 & - & & 3.25 & - & - \\
\hline & Presence & 6.25 & 5 & 6.5 & 0.5 & 3.5 & 0.5 & 0.25 & - & 7 & - & & 0 & - & - \\
\hline Total (\%) & & 73 & 80.75 & 79.25 & 11.25 & 30.75 & 4.25 & 5 & 0.5 & 66.25 & 1.25 & 2.75 & 9.5 & 0.75 & 0.5 \\
\hline
\end{tabular}

Based on the data, it was observed that higher levels of weed incidence were of the dicot class, which resulted in a smaller incidence of monocots. Possibly these data are related to the applied herbicide that obtained a greater monocot control.

According to Pedini (2000), certain weeds occur in a greater extent in acid soils, being classified as indicator plants, which is the case of the weed Cenchrus spp. that is commonly found in acid soils; the weed Eupatorium bunifolium in poor soils with means to elevated acidity; and the presence of Cynodon dactylon which indicates a fertile soil.

In this experiment, no acid soil indicator plants were found, despite the various rates of limestone used.

\section{Conclusions}

According to the enhancement of the soil's surface liming rate, the frequency of dicot weeds is higher, and the frequency of monocots are smaller. 
The soil acidity reduction along with the elevation of the $\mathrm{Ca}$ levels, and the reduction in the levels of $\mathrm{Mg}$ increase the frequency of dicot weeds and reduces monocot weeds.

There is no effect of the herbicide association imazapyr + imazapic on the weed frequency neither interaction with liming rates, indicating that surface-liming do not interfere on the control effectiveness of the herbicides, and consequently on the weed frequency of dicots and monocots.

The most abundant weed species observed in the phytosociological survey were: Desmodium spp., Schlechtendalia luzulifolia, Digitaria horizontalis, Raphanus sativus and Cyperus spp. with the predominance of dicot species.

\section{References}

Adegas, F. S., Oliveira, M. F., Vieira, O. V., Prete, C. E. C., Gazziero, D. L. P., \& Voll, E. (2010). Levantamento fitossociológico de plantas daninhas na cultura do girassol. Planta Daninha, 28(4), 705-716. https://doi.org/ 10.1590/S0100-83582010000400002

Ciotta, M. N., Bayer, C., Ernani, P. R., Fontoura, S. M. V., Wobeto, C., \& Albuquerque, J. A. (2004). Manejo da calagem e os componentes da acidez de Latossolo Bruno em plantio direto. Rev. Bras. Ciênc. Solo, 28(2), 317-326. https://doi.org/10.1590/S0100-06832004000200010

Di Tomaso, J. (1995). Approaches for Improving Crop Competitiveness through the Manipulation of Fertilization Strategies. Weed Science, 43(3), 491-497. https://doi.org/10.1017/S0043174500081522

Embrapa. (2013). Sistema brasileiro de classificação dos solos (p. 353). Brasília: Embrapa.

Embrapa. (2016). Sistema Cultivance ${ }^{\circledR}$ Ideal para a rotação de tecnologias na cultura da soja. Retrieved from https://www.embrapa.br/documents/1355202/1529289/Publica\%C3\%A7\%C3\%A3o_Sistema_Cultivance.p df/a44c53ae-eab1-4b47-afdf-3c487558338e

Fraga, D. S., Ruchel, Q., Duarte, T. V., De Oliveira, A. C. B., Vargas, L., \& Agostinetto, D. (2016). Controle de plantas daninhas na cultura da soja submetida a mistura formulada dos herbicidas imazapyr e imazapic. XXX Congresso Brasileiro de Plantas Daninhas. Retrieved from http://ainfo.cnptia.embrapa.br/digital/ bitstream/item/148477/1/ID43795-2016CBCPD30p342.pdf

Heap, I. (2018). The International Survey of Herbicide Resistant Weeds. Retrieved from http://weedscience.org/ Summary/Country.aspx?CountryID=5

Hirose, T. (1995). Canopy structure and photon flux partitioning among species in a herbaceous plant community. Ecology, 76(2), 466-474. https://doi.org/10.2307/1941205

Karam, D. (2008). Cultivo do Sorgo. Embrapa Milho e Sorgo, Sete Lagoas. Retrieved from http://www.cnpms. embrapa.br/publicacoes/sorgo_4_ed/plantasdaninha.htm

Karam, D. (2016). Efeito residual dos herbicidas aplicados na cultura da soja no milho safrinha em sucessão. Embrapa Milho e Sorgo, Sete Lagoas. Retrieved from http://ainfo.cnptia.embrapa.br/digital/bitstream/ item/52817/1/Efeito-residual.pdf

Karam, D., \& Melhorança, A. L. (2000). Plantas daninhas. EMBRAPA. Retrieved from http://www.cnpms. embrapa.br/publicacoes/milho_1_ed/plantasdaninhas.htm

Oliveira, A. R., \& Freitas, S. P. (2008). Levantamento fitossociológico de plantas daninhas em áreas de produção de cana-de-açucar. Embrapa Semiárido-Artigo em periódico indexado (ALICE). https://doi.org/ 10.1590/S0100-83582008000100004

Pedini, S. (2000). Produção e certificação de café orgânico. In L. Zambolim (Ed.), Café: Produtividade, qualidade e sustentabilidade (pp. 333-360). Viçosa, MG: Departamento de Fitopatologia, UFV.

Pitelli, R. A. (1985). Interferência de plantas daninhas em culturas agrícolas. Informe Agropecuário, Belo Horizonte, 11, 16-27.

Pittelkow, F. K., Jakelaitis, A., Conus, L. A., de Oliveira, A. A., Gil, J. de O., De Assis, F. C., \& Borchartt, L. (2009). Interferência de plantas daninhas na cultura da soja transgênica. Global Science and Technology, 2(3), 38-48. Retrieved from http://rv.ifgoiano.edu.br/periodicos/index.php/gst/article/viewFile/91/106

Rodrighero, M. B., Barth, G., \& Caires, E. F. (2015). Aplicação superficial de calcário com diferentes teores de magnésio e granulometrias em sistema plantio direto. Rev. Bras. Ciênc. Solo, 39(6), 1723-1736. https://doi.org/10.1590/01000683rbcs20150036 
Soratto, R. P., \& Crusciol, C. A. C. (2008). Atributos químicos do solo decorrentes da aplicação em superfície de calcário e gesso em sistema plantio direto recém-implantado. Rev. Bras. Ciênc. Solo, 32(2), 675-688. https://doi.org/10.1590/S0100-06832008000200022

Souza, C. A., Figueiredo, B. P., Coelho, C. M. M., Casa, R. T., \& Sangoi, L. (2013). Arquitetura de plantas e produtividade da soja decorrente do uso de redutores de crescimento. Bioscience Journal, 29(3), 634-643.

Souza, D. M. G., Miranda, L. N., \& Oliveira, S. A. (2007). Acidez do solo e sua correção. In R. F. Novais, V. H. Alvarez, N. F. Barros, R. L. F. Fontes, R. B. Cantarutti, \& J. C. L. Neves (Eds.), Fertilidade do solo (pp. 205-274). Viçosa, MG, Sociedade Brasileira de Ciência do Solo.

Tedesco, M. J., Gianello, C., Bissani, C. A., Bohnen, H., \& Wolkweiss, S. J. (1995). Análises de solo, plantas e outros materiais (2nd ed., p. 174). Boletim Técnico, 5. Porto Alegre, Universidade Federal do Rio Grande do Sul.

Vargas, L., \& Roman, E. S. (2006). Manejo e controle de plantas daninhas na cultura de soja. EMBRAPA, Passo Fundo. Retrieved from http://www.cnpt.embrapa.br/biblio/do/p_do62_1.htm

Volpe, A. B., Donadon, C. C., \& Verde, D. de A. (2011). Manejo de plantas daninhas na cultura do milho (Zea mays L). Universidade De São Paulo. Retrieved from http://www.lpv.esalq.usp.br/lpv672/aula5/7\%20-\%20 Revisao\%20grupo\%203\%20-\%20Manejo\%20de\%20plantas\%20daninhas\%20na\%20cultura\%20do\%20mil ho.pdf

\section{Copyrights}

Copyright for this article is retained by the author(s), with first publication rights granted to the journal.

This is an open-access article distributed under the terms and conditions of the Creative Commons Attribution license (http://creativecommons.org/licenses/by/4.0/). 